\title{
Species Diversity of Arbuscular Mycorrhizal (AM) Fungi in Dalli-Rajhara Iron Mine Overburden Dump of Chhattisgarh (Central India)
}

\author{
Poonam Verma* and R.K. Verma \\ Forest Pathology Division, Tropical Forest Research Institute, Jabalpur - 482 021, \\ Madhya Pradesh, India \\ *Corresponding author
}

\section{A B S T R A C T}

\begin{tabular}{|c|}
\hline Keywords \\
\hline $\begin{array}{l}\text { Degraded land, } \\
\text { Glomeromycota, } \\
\text { Occurrence, Restoration } \\
\text { ecology, Revegetation } \\
\text { strategies, Relative } \\
\text { spore density. }\end{array}$ \\
\hline Article Info \\
\hline $\begin{array}{l}\text { Accepted: } \\
\text { 25 January } 2017 \\
\text { Available Online: } \\
\text { 10 February } 2017\end{array}$ \\
\hline
\end{tabular}

We investigated the diversity of AM fungi in Dalli-Rajhara (Chhattisgarh, India) mine overburden $(\mathrm{OB})$ dump and compares with natural forest soils of adjoining areas. Soil samples were collected from rhizosphere region of planted and naturally growing tree species in mine OB dump. AM spore was isolated by wet sieving and decanting and sucrose floatation method, spore density (per $100 \mathrm{~g}$ dry soil) was calculated. On the basis of morphological character isolated AM fungi of 9 families and 10 genera were identified namely, Ambisporaceae (Ambispora), Archaeosporaceae (Archaeospora), Acaulosporaceae (Acaulospora), Diversisporaceae (Diversispora), Entrophosporaceae (Entrophospora), Gigasporaceae (Gigaspora, Scutellospora), Pacisporaceae (Pacispora), Glomeraceae (Glomus) and Paraglomaceae (Paraglomus). Total 71 species were identified among them Glomus spp. was found to be the most taxonomically diverse with 18 to 29 species followed by Acaulospora spp. (10-16 species).

\section{Introduction}

The nature bestowed India with highly valuable forest and rich mineral resources. Throughout the human civilization, human has been exploiting these resources without bothering for replenishment. In mining area exploitation of mineral resources is the stepping stone for development (Ghosh, 1990). Mining is the second largest industry after agriculture and has played a vital role in the growth of civilization from ancient days (Khoshoo, 1984). It contribute 2nd to the national GDP (Gross Domestic Product) (4\%) occupying 36 lakh ha $(0.11 \%)$ of total land area (329 $\mathrm{m}$ ha) and providing employment generation for 1.1 million people of the country (Saviour, 2012). Chhattisgarh is the richest state in terms of mineral wealth with 28 varieties. Rich deposits of bauxite, limestone, dolomite, coal, iron ore and limestone. Deposits of diamonds, gold, base metal, alexandrite, gemstones, beryl, garnet and rock crystal and corundum are found in the state (CMDC).

Exploitation of mineral resources cannot be avoided since it provides raw materials for many industries. The expansion programme of mining is very fast due to demand of raw 
materials. India possesses large resources of good quality iron ore produced about 73.5 million tons of iron ore in 1999-2000 from both public sector and private sector mines and its demand of iron ore will be 190 million tons; similarly, exports have been estimated to be around 100 million tons by 2019-20 (CPCB, 2007). Vast areas of land all over the world have become unproductive by mining activity (Dhar and Thakur, 1995). It is known to leave behind an environmentally and ecologically unpleasant and un-aesthetic landscape (Singh, 2007). It exerts a long lasting impact on landscape, eco-system and socio-cultural-economic considerations (Sahu and Dash, 2011). For iron ore mine, the stripping ratio range around 2-2.5. These means that for every ton of iron ore produced, double the quantity of waste is generated (SAIL, 2008). In mining activity soil was completely altered on the basis of physicochemical properties. After mining plantation was done in degraded land by mining authority. After plantation it was observed that physicochemical properties of soil gradually improved along with the plant age and the concentration of trace elements decreased (Verma et al., 2017a).

Arbuscular mycorrhizae fungi, belonging to the phylum Glomeromycota (Schubler et al 2001), are obligate symbionts and form associations with about $80 \%$ of plant species (Trappe 1987). Arbuscular mycorrhizal associations are the most frequent symbioses found in nature because of their broad association with plants and cosmopolitan distribution (Harley and Smith 1983; Verma, 2010).

The structural and functional aspects of this association, as evident from fossil records, appear to be quite conserved through time (Phipps and Taylor, 1996; Harley and Smith, 1983). This benevolent relationship has not only helped the emergence of first land plants (Pirozynski and Malloch, 1975) but also supported further successional establishment in widely diversified environments, viz. agricultural soils (Abott and Robson, 1978), mine soils (Jasper et al., 1991), coal wastes (Daft and Hacskaylo, 1976; 1977; Nicolson and Johnston, 1979) alkaline soils, desert soils (Sastry and Johri, 1999) and other habitats. Thus, they play a key role in sustainable conservation of tropical gene pool and diversity (Herrera et al., 1997). Furthermore, through millions of years of succession, evolution, selection and co-existence, AM fungi have helped in refining the soil quality, texture, structure, fertility and compatibility to suit the indigenous plant species. This microbial component of the plant rhizosphere endows a major task in determining plant species diversity (Moora and Zobel, 1996) and helps in stabilizing highly complex diversity regime of the tropical forests. Unfortunately, a large number of man-made and natural eco-sites have not been studied for the occurrence and the extent of dependency of the plant cover on AM fungi, particularly those representing stressed ecosystems. Now a day's application of AM fungi during raising seedlings is helpful for growth of different seedlings in nurseries condition (Verma and Verma, 2016; Verma et al., 2016; Verma et al., 2017).

It has now become necessary to measure the status of existence of AM fungi in disturbed sites. Against this background, in the present investigations, an attempt was made to determine the arbuscular mycorrhizal status of in Dalli Rajhara mine overburden soil in terms of occurrence of arbuscular mycorrhizal fungi.

\section{Materials and Methods}

\section{Study Area}

The selected Dalli-Rajhara mine is under Steel Authority of India Limited (SAIL), which is opencast. It is located $100 \mathrm{~km}$ away 
from Bhilai Nagar city, Central India. It is situated at the geographic location of $20^{\circ} 33^{\prime} 0^{\prime \prime}$ and $20^{\circ} 34^{\prime} 30^{\prime \prime} \mathrm{N}$ latitude and $81^{\circ} 1^{\prime} 0^{\prime \prime}$ and $81^{\circ} 4^{\prime} 30^{\prime \prime} \mathrm{E}$ longitude and Rajhara mines are bounded by $20^{\circ} 33^{\prime} 0^{\prime \prime}$ and $20^{\circ} 35^{\prime} 0^{\prime \prime} \mathrm{N}$ latitude and $81^{\circ} 0^{\prime} 45^{\prime \prime}$ and $81^{\circ} 07^{\prime} 0^{\prime \prime} \mathrm{E}$ longitude. The vegetation of natural forest is dominated by teak (Tectona grandis Linn. F.).

\section{Sample collection}

Waste samples were collected from different age series dump by random sampling method. The samples were collected randomly from 0 $15 \mathrm{~cm}$ depth by digging pits $(15 \times 15 \times 15 \mathrm{~cm})$ from five sites for each dump. Samples were collected both from the rhizosphere of plants and from bulk soil and finally mixed to get a homogenous mixture. These sub-samples were brought to the laboratory in sterilized polythene bags and mixed thoroughly to form a composite sample. After sorting out larger pieces of materials and root fragments, the samples were subjected to sieving in $2 \mathrm{~mm}$ mesh. Each of the samples was divided into three replicates for analysis. Soil sample from adjoining area of the waste dump was taken as control (Parkinson, 1979).

AM fungi species was isolated by wet sieving and decanting technique (Gerdemann and Nicolson 1963; Sylvia, 1994) and spore density (per 100g dry soil) were measured and described by using the data obtained; the following indices of species structure were assessed:

a) Species richness $=$ No. of species present in a particular site

b) Relative spore density $=\mathrm{x} 100$ Spore density of a particular species Spore density of all species

c) Shannon Diversity Index $(\mathrm{H})$ as per Shannon and Wiener (1963): $\mathrm{H}=-\Sigma$ (ni / N ln ni / N) Where, ni = Relative spore density of each species; $\mathrm{N}=$ Total Relative spore density of all species

d) Simpson Diversity index $=1-\mathrm{D}$ As per Simpson (1949), where D (Simpson Dominance Index $)=\Sigma($ ni / N $) 2$; Where, $n i=$ Relative spore density of each species $\mathrm{N}=$ Total Relative density of all species

e) Evenness index (J) as per (Pielous, 1975) $\mathbf{J}$ $=\mathrm{H} / \mathrm{ln} \mathrm{S}$ Where, $\mathrm{H}=$ Shannon Diversity Index; $\mathrm{S}=$ Total no. of species

\section{Results and Discussion}

Total 119 soil samples were collected from rhizosphere region of planted and naturally growing tree species in mine OB dump and NS (natural, undisturbed soil). Name of planted and naturally growing tree species was followed Ailanthus excelsa Roxbs., Albizia lebbeck Benth., Annona squamosa L., Artocarpus heterophyllus Lam., Azadirachta indica A. Juss., Bamboo sp., Butea monosperma (Lam.) Taub., Cassia siamea Lam., Cassia fistula L., Dalbergia sissoo DC., Delonix regia (Hook.) Raf., Eucalyptus hybrid, Eugenia jambolana Lamk., Ficus benghalensis L., Ficus religiosa L., Gmelina arborea Linn., Gmelina robusta A. Cunn., Leucaena leucocephala (Lam.) de Wit, Mangifera indica L., Moringa pterygosperma Gaertn., Peltrophorum ptercocarpus (DC.) K. Heyne, Phyllanthus officinalis L., Polyalthia longifolia (Sonn.) Thwaites, Pongamia pinnata (L.) Pierre, Psidium guajava L., Tamarindus indica L., Tectona grandis L.f., Terminalia arjuna (Roxb. ex DC.) Wight \& Arn., Acacia auriculiformis A. Cunn. ex Benth., Acacia nilotica (L.) Delile, Ailanthus excelsa Roxbs., Albizia lebbeck (L.) Benth., Albizia odoratissima (L.f.) Benth., Alternanthera sessilis (L.) R. Br. ex DC., Anogeissum latifolia Wall, Argemone maxicana L., Azadirachta indica A. Juss, 
Blumea alata (D. Don) DC., Butea monosperma (Lam.) Taub., Calotropis procera R. Br., Cassia alata L., Dalbergia sissoo DC., Dodonaea viscosa Linn., Hyptis suaveolens (L.) Poit, Lantana camara L., Nerium indicum Mill, Tecomas stans (L.) Juss. ex Kunth, Tridax procumbens L., Woodfodiya fruticosa (L.) Kurz, Ziziphus jujuba Lam.

Isolated AM fungi belongs to 9 families and 10 genera, Ambisporaceae (Ambispora), Archaeosporaceae (Archaeospora), Acaulosporaceae (Acaulospora), Diversisporaceae (Diversispora), Entrophosporaceae (Entrophospora), Gigasporaceae (Gigaspora, Scutellospora), Pacisporaceae (Pacispora), Glomeraceae (Glomus) and Paraglomaceae (Paraglomus) (Fig 2).

\section{Species richness and diversity of AM fungi}

As evident from the table 1, all the 71 different AM species were isolated from the NS. However from the fresh dump $\left(D_{0}\right)$, no mycorrhizal spores could be detected. From the subsequent age series dumps $\left(\mathrm{D}_{3}, \mathrm{D}_{7}, \mathrm{D}_{8}\right.$ and $\mathrm{D}_{9}$ ) the numbers of species encountered were 51, 49, 38 and 48 respectively.

All the 71 detected species of AM fungi belong to 10 genera (Fig 2) and the genus Glomus was noted to be the taxonomically most diverse with 18 to 29 species. Dominance of Glomus was followed by Acaulospora.

Species like Gigaspora sp., Glomus etunicatum, G. microcarpum and G. mosseae absent only in 3 year old dump. In 7 year old dump Acaulospora denticulata, Glomus caledonium and Pacispora scintillans species was absent. In 8 year old dump total 11 species Acaulospora bireticulata, A. laevis, A. mellea, Glomus clarum, G. constrictum, G. diaphanum, G. geosporum, G. minutum, $G$. trimurales and Paraglomus laccatum was absent. Species like Acaulospora koskei, A. scrobiculata, A. thomii, Entrophospora schenckki and Scutellospora nigra was absent only in 9 year old dump. Acaulospora cavernata, A. foveata, A. lacunosa, A. rehmii, Entrophospora sp., Gigaspora gigantea, Glomus claroides, G. clavisporum, $G$. coronatum, G. deserticola, G. gibbosum, $G$. invermaium, G. macrocarpum, G. rubiforme, G. tortuosum, Pacispora franciscana, Scutellospora heterogama and Scutellospora sp. were detected in all waste dumps (Table 3).

Species like Ambispora callosa and Glomus xanthium were recorded in NS but not recorded in $\mathrm{D}_{3}, \mathrm{D}_{7}, \mathrm{D}_{8}$ and $\mathrm{D}_{9}$. Glomus fasciculatum, G. luteum, G. multiforum and $G$. nanolumen were only present in 3 years old dump. $G$. insculptum and $G$. intraradices only present in 8 year old dump. G. walkeri was only present in 7 year old dump. Ambispora appendicula, Diversispora spurca, Gigaspora margarita was only present in 9 year old dump. Species like Acaulospora delicata and A. trappei was absent in 3 and 9 year old dump. Acaulospora spinosa, Archaeospora trappei, Entrophospora baltica, Glomus reticulatum and $G$. versiforme were absent in 8 and 9 year old dumps. G. aggregatum, G. monosporum, $G$. heterosporum, G. lamellosum were absent in 7 and 8 year old dumps. G. ambisporum and Scutellospora pellucida was absent in 3 and 7 year dump. In 7 and 9 year old dump Glomus callosum and Glomus flavisproum was absent (Table 3).

Value of species richness, species diversity and evenness of fungi are tabulated in table 1. In dump soil species richness was highest in 3 year old plantation (51) and this gradually decreased with increasing age of $\mathrm{OB}$, expect for 8 year old plantation (38). When compared with species richness of NS (71 species) the OB soil. Shannon wiener diversity index was 1.4 in all age dump soil 
and NS, expect 8 year old plantation. Simpson diversity index of all age dumps and NS was all most similar, expect 8 year old plantation. The species evenness ranges from zero to one with zero signifying no evenness and one a complete evenness. The value of evenness ranged between 0.7763-0.86177, which is near complete evenness. Maximum evenness in dump soil was observed in 3 year old plantation followed by 8 year old plantation. Nine and seven year old plantation have almost similar evenness index. The value of evenness index indicated even distribution of the different AM species in all the waste dumps.

\section{Similarity index (Sorensen coefficient) of AM fungi}

As per data (Table 2) analysis it was found that species similarity in different age $O B$ dumps. Three year and seven years old dumps species similarity was $76.77 \%$. Maximum species similarity was observed in between 3 year old plantation and natural soil $(82.64 \%)$ followed by between 7 year old plantation and natural soil $(80.67 \%)$ and 9 year old plantation and natural soil (80.67\%). Minimum species similarity was observed in between 7 and 8 year old plantation $(60.42 \%)$ followed by between 8 and 9 year old plantation $(60.42 \%)$.

\section{SHE analysis of AM fungi}

Modified SHE analysis was undertaken to observe the changes in pattern of Species richness $(\mathrm{S})$, Diversity $\left(\mathrm{H}^{\prime}\right)$ and Evenness $(\mathrm{E})$ with the increase age of OB dump. The figure (1) shows that with the increasing age species richness is increasing, the diversity in the OB dumps has decreased from 3 year old dump to 7 year old dump after which it remains constant. The Evenness was constant in all the dumps. AM spore is more influence by species richness with the increase in richness the diversity increased there was negligible effect of evenness ( $\left.J^{\prime}\right)$ on the Diversity index (fig 1).

Mycorrhizae are composed of a complex number of species, which differ in their environment tolerances, physical requirement and most importantly their habitat adaptation. The occurrence and distribution of AM fungi varies with physio-chemical properties of soil. The density of propagules varies from site to site and plant to plant (Allen and Allen, 1980). The measure the potential importance of AM fungi in the recovery of disturbed site and land reclamation. It has now become necessary to measure the status of existence of AM fungi in disturbed sites.

The distribution of AM fungi in stressed soils of iron ore sites was study by Kullu and Behera, 2012; Sastry and Johri, 1999; Jasper et al., 1987. Barea et al., 1997; Sanchez-Diaz et al., 1990; Mehrotra, 1995; Evelin et al., 2009; Singh, 2007; Mukhopadhyay and Maiti, 2010 reported that with the improvement of the spoil physico-chemical properties there is an establishment of mycorrhizae in mine spoil OB dumps and such development is expected to play a major role for the plant nutrition ultimately helping in reclamation of the dump.

In the present study as many as 71 mycorrhizae species was recorded the genus Glomus spp. was noted to be most abundant mycorrhizae in the mine spoil dump and it was followed by Acaulospora spp. Availability of Glomus spp. with respect to wild, soil and environmental conditions and host species has been reported by earlier workers (Jha et al., 1994; Ruiz-Lozano, 2003; Pande and Tarafda, 2004; Vivas et al., 2005; Sharma et al., 2009; Cano-Bago, 2009; Kullu and Bahera, 2012). The dominance of this genus has been ascribed due to its smaller sized spores, which are reported to take 
shorter duration to sporulate and reproduce (Nandakwang et al., 2008). As noted in the present study, three genera Glomus, Acaulospora, and Scutellospora were the major contributor to this spore density. And this is in confirmation with the findings of many workers (Makonese et al., 1999; Sharma et al., 2009; Sarwade et al., 2011). These results were similar with present finding.

The mycorrhizae spore density which exhibited increasing trend with increasing age of the dump is in confirmation with the findings of earlier workers (Loree and Williams, 1987;Williamson and Johnson, 1991; Mukhopadhyay and Maiti, 2010; Kullu and Behera, 2012). But in present finding observed that no correlation with age, three year dump have maximum spore and its reduced with increasing age of dumps expect eight year dumps. These may be due to age of dump was increase invasive species was grown, and root colonization with invasive species was very poor or absent (Simelane 2002; Sharm et al., 2005; Bhale et al.,2011; Chandra and Kehri, 2006). Diversity of the AM fungal communities have been related the diversity of the plant communities (Rabatin and Stinner, 1989).

As the age of the sponge iron waste dump increases, diversity of the plant also increases (Kullu and Behera, 2012), this can be correlated with the increasing diversity of the AM fungi in different age series sponge iron solid waste dump.

Gour et al., (1998) reported the occurrence of AM fungi along with tree species namely Terminalia arjuna, Syzygium cuminii. Populas euphartica and naturally grown Typha elephetina at rehabilitated water logged site. They reported that genera Glomus and Gigaspora were the dominant ones. Mukerji and Kappor, (1986) reported the dominance of $G$. mosseae and $G$. fasciculatum in alkaline soils. Unyal, (2001) reported varied density of AM fungi which Glomus macrocarpum dominated in phosphate mined area. The distribution of AM spores in mine spoils may also be affected by carriers like wind and animals, which dispersed the fungi to new habitat (Allen and Allen, 1992).

Ganesan et al., (1991) reported Glomus aggregatum as a common species in coal, lignite and calcite mine spoils in India. Selvam and Mahadevan, (2002) surveyed the fly ash pond and mined sites of Neyveli Lignite corporation in Tamil nadu and found $15 \mathrm{AM}$ fungi species in ash pond, $4 \mathrm{AM}$ fungi species in $\mathrm{OB}$ dumps and 13 AM fungi species in reclaimed $\mathrm{OB}$. In the entire site, Glomus mosseae was the dominant AM fungus.

Mehrotra and Prakash, (2006) reported occurrence of 9 described AM fungi species viz. Acaulospora scrobiculata, Glomus geosporum, G. aggregatum, G. tortuosum, $G$. microaggregatum, $G$ rubiformis, $G$. intraradices, Scutellospora calospora and Entrophospora colombiana from a reclaimed surface mining $\mathrm{OB}$ at the Jayant open cast coal mine site of Northern coalfields Ltd., Singrauli, Uttar Pradesh. But in present finding in 3 year dump Glomus lamellosum, 8 year dump Glomus microcarpum, 9 year dump Glomus diaphanum and in natural soil Glomus deserticola.

Chandra and Jamaluddin, (1999) reported that the occurrence of AM fungi namely Acaulospora, Glomus, Gigaspora, Scutellospora and Sclerocystis genus in coal mine spoils along with 13 forest tree species of different age groups. They also reported that the genus Acaulospora was most dominant fungi in coal mine spoil while Glomus and Gigaspora species also got significant position. Tarafdar and Rao, (1990) 
recorded Acaculospora from the rhizosphere of Azadirachta indica, Parkinsonia aculeata, Albizia lebbek and Zizyphus mauritiana. But in present finding only in 7 year dump Acaulospora biretiulata was dominated.

The endomycorrhiza form Arbuscules (Gianinazzi and Gianinazzi-Pearson, 1986), Vesicles and Pelotons (Powell and Bagyaraj, 1984) and some genera produce auxiliary cells, found to occur in more than $90 \%$ of vascular plants (Gerdemann, 1968; Sylvia et al., 1993).

The arbuscules are the most significant structures in $\mathrm{AM}$ and is the site for the exchange of carbon and phosphate metabolite between the fungus and plant (Smith and Smith, 1990). These structures contain dense non-vacuolated cytoplasm during early stage of development and vacuolation increases with maturity. Vesicles are the lipid filled storage organs (Cox et al., 1975). The external mycelium is dimorphic (Nicolson, 1959) and is essentially a non septate one with one sided angular projections (Butler, 1939).

The occurrence of genus Gigaspora in the rhizosphere was reported in Acacia Senegal and Casuarina equsltifolia by Diem et al., (1981) and in Acacia amera, A. tortilis, Azadirachta indica, Bauhinia racemosa, Eucalyptus camaldulensis and Prosopis juliflora by Tarafdar and Rao, (1990). Another genus Sclerocystis was recorded from Tectona grandis and Dalbergia sissoo by Gerdemann and Bakshi, (1976). Both AM fungi were also isolated from our study site mine land OB. Kumar et al., (2003) reported AM spore density and their colonization also positively correlated.

The most commonly genus of AM spores found are Glomus, Gigaspora, Acaulospora, Enterophospora and Sclerocystis. Glomus and their size frequency distribution range from 50-75 $\mu \mathrm{m}$ and 75-100 $\mu \mathrm{m}$.

The highest number of AM spore density/5 g of soil were found as $360.0 \pm 12.5$ and for AM spore density/100g of soil were found as $702.0 \pm 23.87$ in mine 3 followed by 193.0 \pm 9.45 mine 2 and $174.0 \pm 11.67$ mine. The highest number of AM spore density was reported under the Acacia auriculoloformis.

Table.1 Species richness and diversity of AM fungi in iron ore waste dump and natural soil $((\mathrm{D} 0=$ fresh dump, D3 =three years old dump, D7 = seven year, D8 eight year and D9 = nine year old dump)

\begin{tabular}{|c|c|c|c|c|c|}
\hline \multirow{2}{*}{ S.No. } & \multirow{2}{*}{$\begin{array}{c}\text { Waste } \\
\text { dumps }\end{array}$} & \multirow{2}{*}{$\begin{array}{c}\text { Species } \\
\text { richness }\end{array}$} & \multicolumn{2}{|c|}{ Diversity index } & $\begin{array}{c}\text { Evenness } \\
\text { index }\end{array}$ \\
\cline { 4 - 6 } & & & Shannon & Simpson & \\
\hline 1. & $\mathrm{D}_{0}$ & - & - & - & - \\
\hline 2. & $\mathrm{D}_{3}$ & 51 & 1.44885 & 0.95096 & 0.86177 \\
\hline 3. & $\mathrm{D}_{7}$ & 49 & 1.43715 & 0.95846 & 0.7763 \\
\hline 4. & $\mathrm{D}_{8}$ & 38 & 1.29739 & 0.93952 & 0.84715 \\
\hline 5. & $\mathrm{D}_{9}$ & 48 & 1.43949 & 0.95715 & 0.7775 \\
\hline 6. & $\mathrm{NS}$ & 71 & 1.46709 & 0.94626 & 0.79248 \\
\hline
\end{tabular}


Table.2 Similarity index (Sorensen coefficient) of AM fungi ((D0= fresh dump, D3 =three years old dump, D7 = seven year, D8 eight year and D9 = nine year old dump)

\begin{tabular}{|c|c|c|c|c|c|}
\hline & $\mathrm{D}_{3}$ & $\mathrm{D}_{7}$ & $\mathrm{D}_{8}$ & $\mathrm{D}_{9}$ & $\mathrm{NS}$ \\
\hline $\mathrm{D}_{3}$ & 1 & & & & \\
\hline $\mathrm{D}_{7}$ & 76.77 & 1 & & & \\
\hline $\mathrm{D}_{8}$ & 62.92 & 60.42 & 1 & & \\
\hline $\mathrm{D}_{9}$ & 70.71 & 72.92 & 62.79 & 1 & 1 \\
\hline $\mathrm{NS}$ & 82.64 & 80.67 & 69.72 & 80.67 & 1 \\
\hline
\end{tabular}

Table.3 Relative spore density of AM fungi ((D0= fresh dump, D3 =three years old dump, D7 = seven year, D8 eight year and D9 = nine year old dump)

\begin{tabular}{|c|c|c|c|c|c|c|}
\hline \multirow[t]{2}{*}{ S. No. } & \multirow[t]{2}{*}{ Name of AM fungi } & \multicolumn{5}{|c|}{ Relative spore density } \\
\hline & & D3 & D7 & D8 & D9 & NS \\
\hline 1 & Acaulospora bireticulata & 2.88 & 3.53 & 0 & 3.16 & 2.8 \\
\hline 2 & A. cavernata & 0.15 & 1.09 & 0.33 & 0.81 & 0.147 \\
\hline 3 & A. delicate & 0 & 0.82 & 0.33 & 0 & 0.221 \\
\hline 4 & A. denticulate & 0.08 & 0 & 4.84 & 0.73 & 0.221 \\
\hline 5 & A. foveata & 0.91 & 3.26 & 1.17 & 0.08 & 0.295 \\
\hline 6 & A. koskei & 3.03 & 1.36 & 0.5 & 0 & 0.074 \\
\hline 7 & A. lacunose & 2.42 & 2.85 & 0.83 & 1.94 & 2.579 \\
\hline 8 & A. laevis & 0.15 & 2.45 & 0 & 0.32 & 3.021 \\
\hline 9 & A. mellea & 2.57 & 1.09 & 0 & 0.49 & 0.221 \\
\hline 10 & A. rehmii & 0.45 & 2.85 & 7.01 & 3.08 & 3.095 \\
\hline 11 & A. scrobiculata & 4.012 & 2.85 & 0.67 & 0 & 3.611 \\
\hline 12 & A. spinosa & 0.53 & 2.85 & 0 & 0 & 0.147 \\
\hline 13 & A. thomii & 0.3 & 0.54 & 0.33 & 0 & 0.368 \\
\hline 14 & A. trappei & 0 & 0.41 & 0.33 & 0 & 0.221 \\
\hline 15 & Ambispora appendicula & 0 & 0 & 0 & 0.97 & 0.147 \\
\hline 16 & A. callosa & 0 & 0 & 0 & 0 & 0.074 \\
\hline 17 & A. fennica & 0 & 1.09 & 0 & 6.8 & 0.516 \\
\hline 18 & Archaeospora trappe & 0.45 & 0.14 & 0 & 0 & 0.147 \\
\hline 19 & Diversispora spura & 0 & 0 & 0 & 3.97 & 2.063 \\
\hline 20 & Entrophospra baltica & 0.23 & 0.54 & 0 & 0 & 0.295 \\
\hline 21 & E. schenckki & 2.35 & 0.27 & 0.84 & 0 & 1.326 \\
\hline 22 & Entrophospra sp. & 0.68 & 1.22 & 4.84 & 0.4 & 0.221 \\
\hline 23 & Gigaspora gigantean & 3.18 & 4.35 & 7.01 & 3.97 & 0.368 \\
\hline 24 & G. margarita & 0 & 0 & 0 & 0.16 & 2.874 \\
\hline 25 & Gigaspora sp. & 0 & 2.99 & 3.56 & 2.59 & 0.442 \\
\hline 26 & Glomus aggregatum & 1.59 & 0 & 0 & 0.08 & 7.148 \\
\hline
\end{tabular}




\begin{tabular}{|c|c|c|c|c|c|c|}
\hline 27 & G. ambisporum & 0 & 0 & 0.5 & 0.08 & 1.179 \\
\hline 28 & G. callosum & 2.35 & 0 & 0.33 & 0 & 0.295 \\
\hline 29 & G. caledonium & 0.15 & 0 & 0.17 & 0.16 & 0.368 \\
\hline 30 & G. claroides & 0.3 & 3.13 & 7.01 & 3.64 & 0.221 \\
\hline 31 & G. clarum & 4.47 & 0.4 & 0 & 3.08 & 0.368 \\
\hline 32 & G. clavisporum & 2.73 & 3.26 & 8.85 & 6.4 & 0.147 \\
\hline 33 & G.constrictum & 1.44 & 2.85 & 0 & 0.81 & 2.8 \\
\hline 34 & G. coronatum & 1.21 & 1.63 & 3.84 & 3.4 & 1.4 \\
\hline 35 & G. deserticola & 2.04 & 5.3 & 9.85 & 7.21 & 3.464 \\
\hline 36 & G. diaphanum & 5.45 & 1.09 & 0 & 5.26 & 0.59 \\
\hline 37 & G. etunicatum & 0 & 3.26 & 8.01 & 2.75 & 1.548 \\
\hline 38 & G. fasciculatum & 0.61 & 0 & 0 & 0 & 12.45 \\
\hline 39 & G. flavisproum & 0.91 & 0 & 0.33 & 0 & 0.147 \\
\hline 40 & G. geosporum & 1.82 & 0.82 & 0 & 1.7 & 4.716 \\
\hline 41 & G. gibbosum & 2.12 & 7.61 & 4.17 & 5.59 & 0.147 \\
\hline 42 & G. heterosporum & 3.56 & 0 & 0 & 0.08 & 0.147 \\
\hline 43 & G. insculptum & 0 & 0 & 0.33 & 0 & 0.368 \\
\hline 44 & G. intraradices & 0 & 0 & 0.5 & 0 & 5.306 \\
\hline 45 & G. inveranum & 0.08 & 5.16 & 6.01 & 4.53 & 0.295 \\
\hline 46 & G. lamellosum & 7.95 & 0 & 0 & 0.65 & 0.221 \\
\hline 47 & G. luteum & 2.57 & 0 & 0 & 0 & 0.368 \\
\hline 48 & G. macrocarpum & 0.15 & 1.22 & 5.18 & 0.65 & 7.59 \\
\hline 49 & G. microcarpum & 0 & 8.7 & 6.34 & 5.43 & 1.326 \\
\hline 50 & G. minutum & 13.48 & 0.54 & 0 & 4.78 & 0.074 \\
\hline 51 & G. monosporum & 2.04 & 0 & 0 & 0.08 & 0.295 \\
\hline 52 & G. mosseae & 0 & 0.41 & 0.67 & 4.94 & 10.91 \\
\hline 53 & G. multiforum & 1.97 & 0 & 0 & 0 & 0.221 \\
\hline 54 & G. nanolumen & 0.08 & 0 & 0 & 0 & 0.147 \\
\hline 55 & G. reticulatum & 1.21 & 0.41 & 0 & 0 & 0.516 \\
\hline 56 & G. rubiformi & 0.08 & 6.39 & 4.17 & 1.7 & 0.442 \\
\hline 57 & G. tortuosum & 5.45 & 6.11 & 0.84 & 1.7 & 0.295 \\
\hline 58 & G. trimurales & 5.22 & 1.36 & 0 & 3.97 & 0.074 \\
\hline 59 & G. versiforme & 3.71 & 0.95 & 0 & 0 & 2.063 \\
\hline 60 & G. walker & 0 & 0.27 & 0 & 0 & 1.326 \\
\hline 61 & G. xanthium & 0 & 0 & 0 & 0 & 0.221 \\
\hline 62 & Pacispora franciscan & 0.3 & 0.41 & 0.5 & 0.57 & 0.221 \\
\hline 63 & P. scintillans & 0.38 & 0 & 0.33 & 0.08 & 0.295 \\
\hline 64 & Pacispora sp. & 0 & 0.41 & 0 & 0.16 & 0.442 \\
\hline 65 & Paraglomus lactum & 0.23 & 0.41 & 0 & 0.97 & 2.284 \\
\hline
\end{tabular}




\begin{tabular}{|c|c|c|c|c|c|c|}
\hline 66 & Scutellospora armeniaca & 0 & 0 & 0 & 0.08 & 0.147 \\
\hline 67 & S. gregaria & 0 & 3.53 & 0 & 3.16 & 0.147 \\
\hline 68 & S. heterogama & 2.88 & 1.09 & 0.33 & 0.81 & 0.442 \\
\hline 69 & S. nigra & 0.15 & 0.82 & 0.33 & 0 & 1.105 \\
\hline 70 & S. pellucid & 0 & 0 & 4.84 & 0.73 & 0.074 \\
\hline 71 & Scutellospora sp. & 0.08 & 3.26 & 1.17 & 0.08 & 0.147 \\
\hline
\end{tabular}

Fig.1 SHE analysis of AM fungi

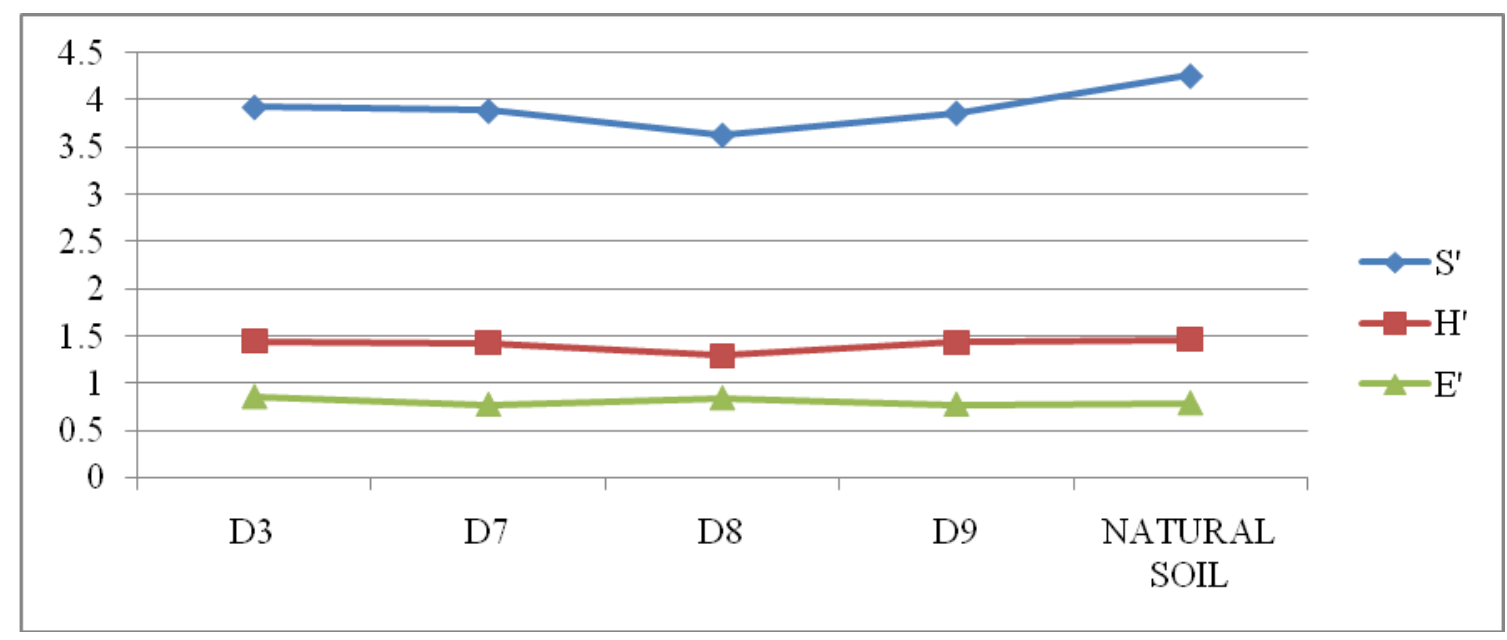

Fig.2 AM genera represented by different number species recorded in iron ore waste dumps and natural soil (NS) (D0 = fresh dump, D3 =three years old dump, D7 = seven year, D8 eight year and $\mathrm{D} 9$ = nine year old dump)

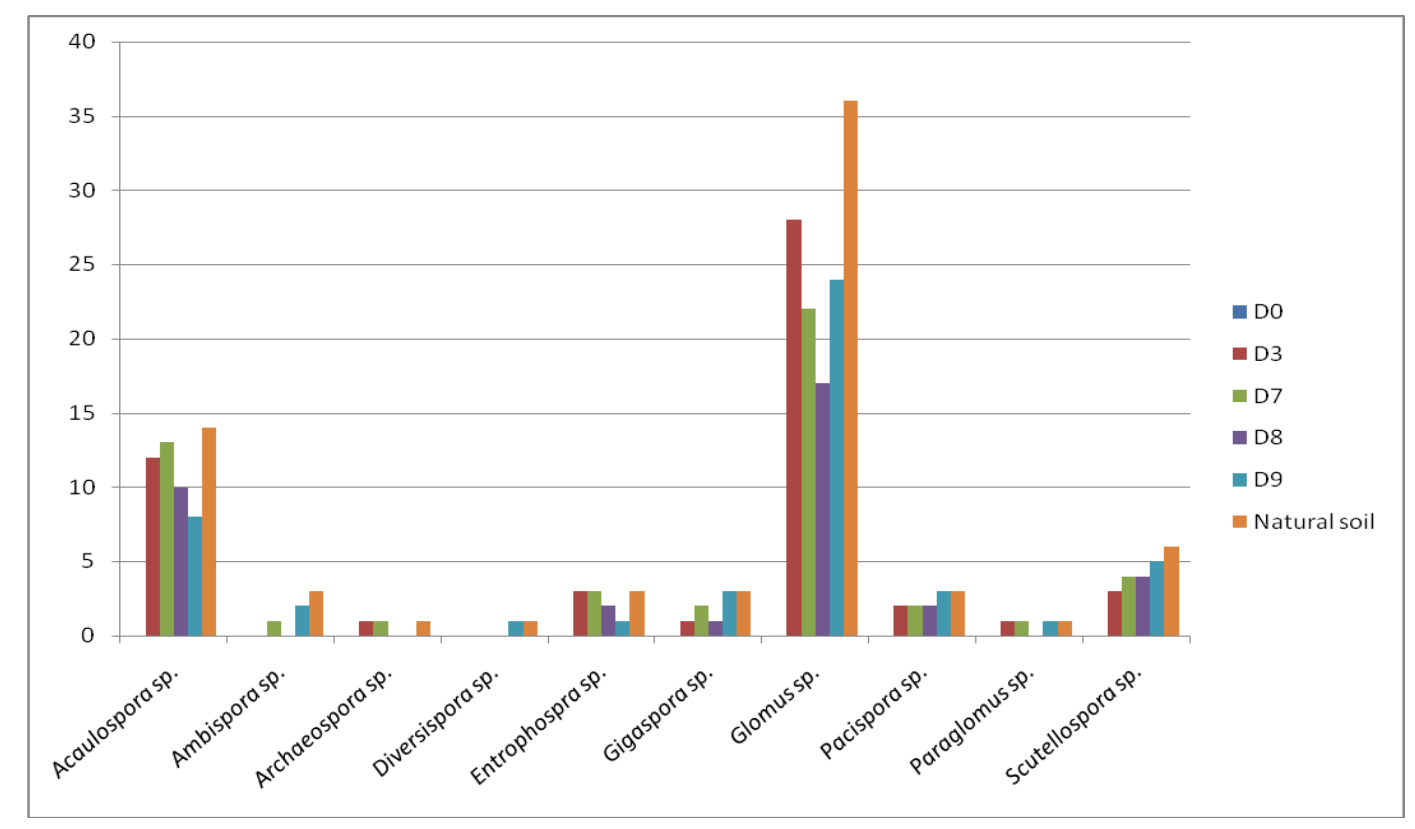

Chong (1988) and Rathi and Singh (1990) reported AM association in Acacia 
auriculiformis, Cassia fistula, C. siamea, Leucaena leucocephela, Samanea saman and Tectona grandis. Raghupathy and Mahadevan (1993) observed the infection of AM in Gmelina arborea and Bamboo spp. Santhaguru et al., (1995) reported that AM infection was $100 \%$ in Albizia amara, Peltophorum pterocarpum and Pongamia glabra.

\section{SHE analysis}

SHE Graph was plotted against the age of the dumps to study the change in phyto sociological characters and species accumulation on the OB dumps with increasing age. the plot (Fig. 1) showed that the species diversity $\left(\mathrm{H}^{\prime}\right)$ was highest in the 3 year old dumps, it decreased in 7 year old dumps after which it was near constant. It may be due to (i) availability of phosphorous was increased due to decomposition of parent rock, increased availability of phosphorous decreases the diversity of mycorhiza in soil (Abbott and Robson, 1977; Smith, 1982; Olsson et al., 1997) (ii) after 7 year of plantation the empty spaces in the plantations were occupied by the fast growing Invasive species, it was found during the study that there was no mycorhizal association with Lanatana camara, this may be one of the reason of low mycorhizal diversity in dumps more than 7 year old. There was no change in evenness of the species with increasing age of dump, while species richness increased through time. It can be concluded from SHE analysis that the diversity index in the overburden areas is mostly regulated by evenness in the community. As observed in the present study, mycorrhizae spore density (in terms of Shannon's diversity index $\mathrm{H}$ ) also showed an increasing trend with the increase in the age of the dump. Such increasing trend has also been noticed by Mukhopadhyay and Maiti, (2010) for some Indian coal mine spoil.
In conclusion, total 71 species of AM fungi belonging 9 families and 10 genera were identified from mine overburden dump and adjoining natural forest soil. Glomus species were found to be the most taxonomically diverse with 18 to 29 species followed by Acaulospora spp (10-16 species).

\section{References}

Abbott, L.K. and Robson, A.D. 1977. Growth stimulation of subterranean clover with vesicular arbuscular mycorrhizae. Australian Journal of Agricultural Research, 28: 639-649.

Abott, L.K. and Robson, A.D. 1978. Growth of subterranean clover in relation to the formation of endomycorrhizas by introduced and indigenous fungi in a field soil. New Phytologist, 81: 575585.

Allen, E. B. and Allen, M.E. 1980. Natural reeshtablishment of VAM following stripmine reclamation in Wyoming. Journal of Applied Ecology, 17: 139-147.

Allen, M.F. and Allen, E.B. 1992. Development of mycorrhiza patches in a successional arid ecosystem, Pp 164170. In: Mycorrhizas in ecosystem, Read DJ, Lewis DH, Fitter AH and Alexander JJ (eds), Cambridge, CAB International.

Barea, J.M., Azcon-Aguilar, C. and Azcon, R. 1997. Interactions between mycorrhizal fungi and rhizosphere microorganisms within the context of sustainable soilplant systems, Pp 65-77. In: Multitrophic interactions in terrestrial systems, Gange AC and Brown VK (eds), Blackwell Science, Oxford.

Bhale, U.N., Sawant, V.S. and Sarwade, P.P. 2011. Arbuscular mycorrhiza of some plants growing in Marathwada region of Maharashtra. Kavaka, 39: 33-36.

Butler, E.J. 1939. The Occurrences and Systematic Position of the Vesicular 
arbuscular Type of Mycorrhizal Fungi. Transactions of the British Mycological Society, 22: 274-301.

Cano, C. and Bago, A. 2005. Competition and substrate colonization strategies of three polyxenically grown arbuscular mycorrhizal fungi. Mycologia, 97: 1201-1214.

Chandra, K.K. and Jamaluddin. 1999. Distribution of vesicular arbuscular mycorrhizal fungi in caol mine overburden dumps. Indian Phytopathology, 52(3): 254-258.

Chandra, S. and Kehri, H.K. 2006. Biotechnology of VA Mycorrhiza: Indian scenario. New India Publishing Agency, New Delh, 413 pp.

Chong, I. 1988. Occurrence of mycorrhizae in seedling o $\mathrm{f}$ some tree species in Sarawak. In. M ycorrhizae for green Asia. Proc. of 1st Asian Con. on Mycorrhizae (Ed. N. Raman), University of Madras, India, pp.70-72.

Cox, G., Sanders F.E., Tinker, P.B. and Wild., J.A. 1975. Ultrastructural evidence relating to host-endophyte transfer in a vesicular-arbuscular mycorrhiza. In: Endomycorrhizas. (Eds. Sanders, F.E., B. Mosse and P.B. Tinker). Academic Press, London pp 279-3.

CPCB. 2007. Development of clean technology for iron ore mines and development of environmental standards (Ministry of environment and forests, Govt. of India).

Daft, M. J. and Hacskaylo, E. 1977. Growth of endomycorrhizal and nonmycorrhizal red maple seedlings in sand and anthracite spoil. Forest Science, 23: 207-216.

Daft, M.J. and Hacskaylo, E. 1976. Arbuscular mycorrhizas in tbe anthracite and bituminous coal wastes of Pennsylvania. Journal of Applied Ecology, 13: 523-531.

Dhar, B.B. and Thakur, D.N. 1995. Mining environment: In proceeding of the 1st world mining environment congress, December 11-14, New Delhi, pp 1038.

Diem, H.G., Gueye, I., Gianinazzi-Pearson, V., Fortin, J.A. and Dommergues, Y.R. 1981. Ecology of VA mycorrhizae in the tropics: The semi-arid zone of Senegal. Acta OecologicaOecologia Plantarum, 16: 53-62.

Evelin, H., Kapoor, R. and Giri, B. 2009. Arbuscular mycorrhizal fungi in alleviation of salt stress. Annals of Botany, 104: 1263-1280.

Ganesan, V., Parthipon, B. and Mahadevan, A. 1991. Survey of vesicular-arbuscular mycorrhizae (VAM) in Kodayar forest, Tamil Nadu, India. Proceedings of the second Asian conference on mycorrhiza, Soerianegara I and Supriyanto (eds), pp 73-75.

Gaur, A.C., Adholeya, A. and Mukerji, K.G. 1998. A comparison of AM fungi inoculants using Capsicum and Polianthes in marginal soil amended with organic matter. Mycorrhiza, 7: 307-312.

Gerdemann, J. W. and Nicolson,T. H. 1963. Spores of mycorrhizal Endogone extracted from soil by wet sieving and decanting. Transactions of the British Mycological Society, 46: 235-244.

Gerdemann, J.W. 1968. Vesicular arbuscular mycorrhiza and plant growth. Annual Review of Phytopathology, 6: 397-418.

Gerdemann, J.W. and Bakshi, B.K. 1976. Endogonaceae of India: Two new species. Transactions of the British Mycological Society, 66: 340-343.

Ghosh, R. 1990. Effect of mining on surrounding land utilization Pp 47-61. In: Impact of mining on environment, Trivedy RK and Sinha MP (eds.) Ashish publishing house, New Delhi $302 \mathrm{pp}$.

Gianinazzi, S. and Gianinazzi-Pearson, V. 1986. Progress and headaches in 
endomycorrhiza biotechnology. Symbiosis, 2: 139-149.

Harley, J.L. and Smith, S.E. 1983. Mycorrhizal symbiosis. London, UK: Academic Press. 483 p.

Hayman, D.S. 1982. Influence of soils and fertility on activity and survival of vesicular-arbuscular mycorrhizal fungi. Phytopathlogy, 72: 1119-1125.

Herrera, R.A., Ulloa, D.R.,Valdes Lafont, O., Priego, A.G and Valdes AR. 1997. Ecotechnologies for the sustainable management of tropical forest diversity. Nature and Resources, 33: 2-17.

Jasper, D.A., Abott, L. and Robson, A.D. 1991. The effect of soil disturbance on vesicular arbuscular mycorrhizal fungi in soils from different vegetation types. New Phytologist, 118: 471-476.

Jasper, D.A., Robson, A.D. and Abbott, L.K. 1988. Revegetation in an iron-ore mine - nutrient requirements for plant growth and the potential role of vesiculararbuscular (VA) mycorrhizal fungi. Australian Journal of Soil Research, 26: 497-507.

Jasper, D.A., Robson, A.D. and Abott, L.K. 1987. The effect on surface mining on the in fectivity of vesicular arbuscular mycorrhizal fungi. Australian Journal of Botany, 35: 641-652.

Jha, D.K., Sharma, G.D. and Mishra, R.R. 1994. Ecology of vesicular-arbuscular mycorrhiza, Pp 199-208. In: Microbes and environments, Prasad $\mathrm{AB}$ and Bilgrami RS (eds.), Narendra publishing house.

Khoshoo, T.N. 1984. Land reclamation in open cast mine. March 10-27th memorial lecture, MMGI, Calcutta, India.

Kullu, B. and Behera, N. 2012. Status and diversity of vesicular arbuscular mycorrhiza in different age series sponge iron solid waste dump with respect to reclamation. The Bioscan,
7(3): 539-542.

Kumar, A., Raghuwanshi, R. and Upadhyay, R.S. 2003. Vesicular-arbuscular mycorrhizal association in naturally revegetated coal mine spoil. Tropical Ecology, 44(2): 253-256.

Loree, M.A.J. and Williams, S.E. 1987. Colonization of western wheatgrass (Agropyron smithii Rydb.) by vesiculararbuscular mycorrhizal fungi during the revegetation of a surface mine. New Phytologist, 106: 735-744.

Makonese, F.T., Mpepereki, S. and Mafongoya, P. 1999. Vesicular arbuscular mycorrhizal fungi prevalence and diversity in Zimbabwean soils. Journal of Applied Science in Southern Africa, 5(1): 35-46.

Mehrotra, V. S. 1998. Arbuscular mycorrhizal associations of plants colonizing coal mine spoil in India. Journal of Agricultural Science, 130: 125-133.

Mehrotra, V.S. 1995. Arbuscular mycorrhizal associations in plants colonizing overburdened soil at an opencast coalmine site, Pp 22-29. In: Mycorrhizae: biofertilizers for the future, Adholeya A and Singh S (eds), Proceedings of the third national conference on mycorrhizae.

Mehrotra, V.S. and Prakash, A.P. 2006. Arbuscular mycorrhizal fungi of the revegetated coal mine spoil of northern India, Pp 11-19. In: Mycorrhiza, Prakash A and Mehrotra VS (eds) Scientific publishers (India), Jodhpur.

Moora, M. and Zobel, M. 1996. Effect of Arbuscular mycorrhizia on inter and intraspecific competition of two grassland species. Oecologia, 108: 7984.

Mukerji, K.G. and Kapoor, A. 1986. Occurrence and importance of vesicular-arbuscular mycorrhizal fungi in semiarid regions of India. Forest Ecology and Management, 16: 117-126. 
Mukhopadhyay, S. and Maiti, S.K. 2010. Eco-restoration of coal mine overburden dumps- with emphasis on mine soil properties, natural VAM colonization, litter accumulation and tree growth. Mine Technology, 31(2): 16-26.

Nandakwang, P., Elliot, S. and Lumyang, S. 2008. Diversity of arbusular mycorrhizal fungi in forest restoration area of Doi Suthep-Pui national park, North Thailand. Journal of Microscopy Society of Thailand, 22: 60-64.

Nicolson, T.H . 1959. Mycorrhizae in the Gramineae I. Vesicular- arbuscular endophytes with special reference to the external phase. Transactions of the British Mycological Society, 42: 421438.

Nicolson, T.H. and Johnston, C. 1979. Mycorrhiza in the Gramineae. III. Glomus fasciculatum as the endophyte of pioneer grasses in a maritime sand dune. Transactions of the British Mycological Society, 72: 261-268.

Olsson, P.A., Baath, E. and Jakobsen, I. 1997. Phosphorus effects on the mycelium and storage structures of an arbuscular mycorrhizal fungus as studied in the soil and roots by analysis of fatty acid signatures. Applied and Environmental Microbiology, 63:3 531-3538.

Pande, M. and Tarafdar, J.F. 2004. Arbuscular mycorrhizal fungal diversity in neem based agroforestry systems in Rajasthan. Applied Soil Ecology, 26:233-241.

Parkinson, D. 1979. Soil microorganisms and plant roots, Pp449-478. In: Soil biology, Burges A and Raw F (eds). Academic Press, New York.

Phipps, C.J. and Taylor, T.N. 1996. Mixed arbuscular-mycorrhizae from the Triassic of Antarctica. Mycologia, 88: 707-714.

Pielou, F.D. 1975. Ecological diversity. Wiley Intescienco, New York.
Pirozynski, K.A. and Malloch, D. 1975. The Origin of land plants: A matter Of Mycotropsim. Biosystems, 6: 153-164.

Powell, C.L. and Bagyaraj, D.J. 1984. VA mycorrhizal. CRC Press, Boca Raton, FL.

Rabatin, S.C. and Stinner, B.R. 1989. The significance of vesicular arbuscular mycorrhizal fungal-soil macro invertebrates interaction ecosystem. Agriculture, Ecosystems and Environment, 27: 195-204.

Raghupathy, S. and Mahadevan, A. 1993. Distribution of vesicular Arbuscular mycorrhizae in plants and rhizosphere soils of the tropic al plains, Tamilnadu, India, Mycorrhiza 3(3): 123 -136.

Rathi, S.K. and Singh, L. 1990. Preliminary survey of mycorrhizal fungi in some weeds and cultivated plants in Meerut. Proc. Workhop on Mycorrhizae pp. 3132. Hariyana Agricultural University, Hissar.

Ruiz-Lozano, J.M. 2003. Arbuscular mycorrhizal symbiosis and alleviation of osmotic stress: new perspectives for molecular studies. Mycorrhiza, 13: 309317.

Sahu, H.B. and Dash, S. 2011. Land degradation due to mining in India and its mitigation measures, $2^{\text {nd }}$ International Conference on Environmental Science and Technology, 6: 132-136.

SAIL. 2008. Ministry of mines, national mineral policy of India. National Government of India.

Sanchez-Diaz, M., Pardo, M., Antolin, M., Pena, J. and Aguirreolea, J. 1990. Effect of water stress on photosynthetic activity in the Medicago-RhizobiumGlomus symbiosis. Plant Science, 71: 215-221.

Santhaguru, K., Gladis Ponmalar, S.D. and Karunakaran, R. 1995. Vesiculararbuscular mycorrhizae in tree legumes 
and its rhizosphere soils of Algar Hills. Indian Forester, 121: 817-823.

Sarwade, P.P., Chandanshive, S.S., Kanade, M.B. and Bhale, U.N. 2011. Diversity of arbuscular mycorrhizal (AM) fungi in some common plants of Marathwada region. International Multidisciplinary Research Journal, 1(12): 11-12.

Sastry, M.S.R. and Johri, B.N. 1999. Arbuscular mycorrhizal fungal diversity of stressed soils of Bailadila iron ore sites in Bastar region of Madhya Pradesh. Current Science, 77: 10951100.

Saviour, M.N. 2012. Environmental impact of soil and sand mining: a review. International Journal of Science, Environment and Technology, 1(3): 125-134.

Schenck, N.C. and Perez, Y. 1987. Manual for the Identification of VA Mycorrhizal Fungi. Second Edition. International Culture Collection of VA Mycorrhizal Fungi, University of Florida, Gainesville, Florida.

Schubler, A., Schwarzott, D. and Walker, C. 2001. A new fungal phylum, the Glomeromycota: phylogeny and evolution. Mycological Research, 105: 1413-1421.

Selvam, A. and Mahadevan , A. 2002. Distribution of mycorrhizas in an abandoned fly ash pond and mined sites of Neyveli lignite corporation, Tamil Nadu, India. Basic and Applied Ecology, 3(3): 277-284.

Shannon, C.E. and Wiener, W. 1963. The Mathematical Theory of Communication. University of Illinois Press, Urbana, USA.

Sharma, D., Kapoor, R. and Bhaytnagar, A.R. 2009. Differential growth response of Curculigo orchoides to native AMF communities varying in number and fungal components. European Journal of Soil Biology, 45(4): 328-333.
Sharma, G.P., Raghubashi, A.S. and Singh, J.S. 2005. L. camara invasive: An overview. Weed Biology and Management, 5: 157-165.

Simelane, D.O. 2002. Biology of host range of Ophiomyia camarae, a biology control agent for L. camara in South Africa. Bio-control, 47: 575-585.

Simpson, E.H. 1949. Measurement of Diversity. Nature, 163: 688.

Singh, A. 2007. Studies on indicator microbes occurring in lime stone mine overburdens and their role in biological rejuvenation of the spoil. Ph.D. thesis, Forest Research Institute (Deemed University), Dehradun.

Singh, A.K. and Jamaluddin. 2011. Status and diversity of arbuscular mycorrhizal fungi and its role in natural regeneration on limestone mined spoils. Biodiversitas, 12(2): 107-111.

Smith, S.E. 1982 Inflow of phosphate into mycorrhizal and non mycorrhizal plants of Trifolium subterraneun of different levels of soil phosphate. New Phytology, 90: 293-303.

Smith, S.E. and Smith, F.A. 1990. Structure and function of the interfaces in biotrophic symbioses as they relate to nutrient transfer. New Phytologist, 114: 1-38.

Sylvia, D.M. 1994. Vescular arbuscular mycorrhizal fungi, $\mathrm{Pp}$ 351-378. In: Method of soil analysis Part 2 Microbiology and biochemical properties Machison. Soil science society of American, Wiscosin.

Sylvia, D.M., Wilson, D.O., Graham, J.H., Maddox, J.J., Millner, P., Morton, J.B., Skipper, H.D., Wright, S.F., Jarstfer, A.G., 1993. Evaluation of vesiculararbuscular mycorrhizal fungi in diverse plants and soils. Soil Biology and Biochemistry, 25: 705713.

Tarafdar, J.C. and Rao, A.V. 1990. Survey of 
Indian arid zone tree species for the occurrence of VAM infections. Pp. 4243 in Jalali, B.L and Chand, H. (Eds.) Current Trends in Mycorrhizal Research. 14-16 February 1990. Haryana Agriculture University, Hisar, Haryana.

Trappe, J. 1987. Phylogenetic and ecologic aspects of mycotrophy in the angiosperms from an evolutionary standpoint. In: Safir GR, ed. Ecophysiology of VA mycorrhizal plants. Boca Raton, Florida, USA: CRC Press. Pp 5-25.

Uniyal, K. 2001. Incidence of arbuscular mycorrhizal fungi in ecologically restored mined area of Doon vally, Indian Forester, 127(6): 690-694.

Verma P and Verma RK (2016) Production of AM fungi in iron ore mined overburden dump soil. Indian Journal of Tropical Biodiversity, 24(2): 117-126.

Verma P, Singh S and Verma RK (2017a) Impact of plantation on iron ore mined overburden at Durg in Chhattisgarh (India). International Research Journal of Environment Science, 6(1):1-12.

Verma P, Mohammad N and Verma RK (2017) Association of arbuscular mycorrhizal fungi with maida chaal (litsea glutinosa lour) seedlings. Global Journal of Bioscience and Biotechnology, 6(1): 157-161.
Verma RK, Thakur AK, Verma P, Mishra Y (2016) A rbuscular mycorrhization and growth performance of Pterocarpus marsupium seedlings raised from different seed sources of Chhattisgarh, India. Indian Journal of Tropical Biodiversity, 24(2): 151-157

Verma RK (2010). Change in microbial diversity under tree plantation on degraded land of Bilaspur (Chhattisgarh). In: Sustainable Rehablitation of Degraded Ecosystem. (Chaubey, O.P., Bahadur, V. and Shukla, P.K., eds.) Pp 177-181. Aaviskar Publishers, Distributors, Jaipur 302p.

Vivas, A., Barea, J.M. and Azcon, R. 2005. Interactive effect of Brevibacillus brevis and Glomus mosseae, both isolated from Cd-contaminated soil, on plant growth, physiological mycorrhizal fungal characteristics and soil enzymatic activities in $\mathrm{Cd}$ polluted soil. Environmental Pollution, 134: 257-266.

Williamson, J.C. and Johnson, D.B. 1991. Studies on the microbiology of soils at opencast coal sites 2. Population transformations occurring following land restoration, and the influence of ryegrass/fertiliser amendments. Journal of Soil Science, 42: 9-15.

\section{How to cite this article:}

Poonam Verma and R.K. Verma. 2017. Species Diversity of Arbuscular mycorrhizal (AM) Fungi in Dalli-Rajhara Iron Mine Overburden Dump of Chhattisgarh (Central India). Int.J.Curr.Microbiol.App.Sci. 6(4): 2766-2781. doi: https://doi.org/10.20546/ijcmas.2017.604.320 